\section{Ética e Psiquiatria}

Alves LC, coordenador. Conselho Regional de Medicina do Estado de São Paulo; 2007.
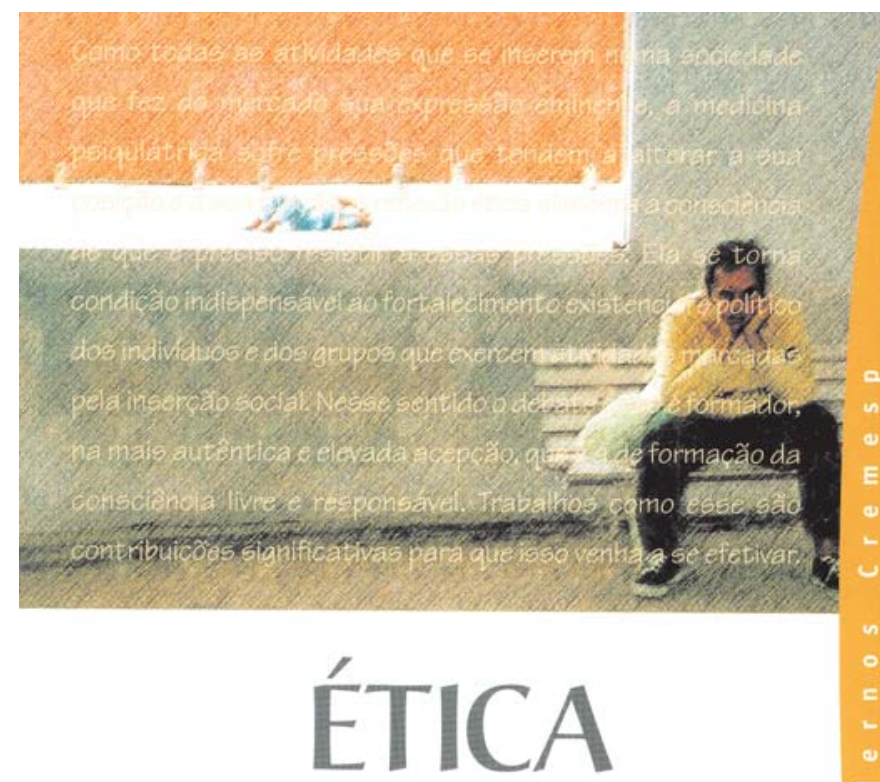

E PSIQUIATRIA
C REM M S P

Conselho Regional de Medicina do Estado de Sào Paulo sua tomada de decisões, embora não o poupe dos conflitos, uma vez que não há uma hierarquia consensual entre os princípios que a constituem. Como exemplo, pode ser citada a difícil decisão entre privilegiar o princípio da autonomia ou o da beneficência/ não-maleficência em cada situação em que haja risco de suicídio. Os autores assumem a dificuldade e a relatividade do ensino da ética e lembram que este mesmo ensino vai além do currículo escolar. Nesse sentido, o comportamento de um professor e sua personalidade revelam mais do que seus próprios ensinamentos.

Um ponto frágil do livro é representado pela não inclusão de conflitos éticos encontrados na prática psiquiátrica pericial. De fato, a despeito da polêmica internacional quanto à viabilidade de se ter ou não diretrizes éticas específicas para a prática forense, essa área de atuação psiquiátrica apresenta conflitos éticos peculiares que não foram abordados, a não ser sob forma de comentários superficiais. Por outro lado, o livro traz outros temas intimamente ligados à psiquiatria legal, como a "espinhosa" matéria (termo dado pelo próprio autor) da internação psiquiátrica involuntária.

Os temas escolhidos pelos autores são importantes, atuais e abordados com uma clareza inquestionável. Eles vêm ao encontro dos tópicos que recebem atenção internacional não só no campo da assistência, que é claramente privilegiado nesta obra, como também ensino e pesquisa, uma vez que os aspectos éticos encontram-se intimamente relacionados nessas três esferas. Suicídio; psicoterapia; o médico com transtorno mental; doença mental e crime; relação do psiquiatra com outros profissionais e com a indústria farmacêutica e do álcool; emergências médicas; erro médico em psiquiatria; psiquiatria da infância; psicocirurgias; e eletroconvulsoterapia: estes são alguns outros temas tratados nos diversos capítulos do livro.

Finalmente, extraio aqui as palavras de Darcy Porlolese, um dos autores do livro: "não se atinge um ápice ético, ele está sempre em construção em meio a um aprender com a experiência...". Nesse sentido, este livro é apenas uma contribuição, mas uma bela contribuição, ao processo contínuo do vir a ser eticamente melhor.

Elias Abdalla-Filho Departamento de Ética e Psiquiatria Legal da Associação Brasileira de Psiquiatria
Este livro, ao contrário de um código rígido de ética, convida o leitor a refletir sobre a ética de várias situações encontradas no exercício da Psiquiatria, sobretudo na esfera assistencial. Ao diferenciar ética de moral, os autores deixam claro o objetivo de se buscar luz sobre conflitos éticos não apenas em situações-limites como também na prática cotidiana.

Para esta finalidade, eles recorrem à bioética e, na dependência do tema tratado, a sociólogos (como Weber e Rustin), filósofos (como Kant), psicanalistas (como Freud, Klein e Bion), psicoterapeutas de grupo (como Ackerman e Moreno) e até mesmo a Rui Barbosa para nortear o raciocínio da ética em psiquiatria e psicoterapia. Um dos próprios autores (Del Sant) chega mesmo a lembrar que "conhecimento nas áreas de psicologia, psicanálise, filosofia, antropologia, direito e inclusive história é obrigatório ao profissional" para o bom exercício da psiquiatria.

A corrente bioética mais utilizada pelos autores é a principialista, o que ratifica ser esta até hoje a linha hegemônica dessa disciplina. Afinal, ela tem o mérito de instrumentalizar o profissional em 